\title{
Media Siber dan Analisis Isi Kuantitatif: Trend Pemberitaan Terhadap Proyek Spam di Lampung
}

\section{Cyber Media and Quantitative Content Analysis: News Trend on Spam Projects in Lampung}

\author{
Eka Yuda Gunawibawa*), Hestin Oktiani, Agung Wibawa \\ 1,2,3 Universitas Lampung, Jl. Soemantri Brojonegoro Gedong Meneng Rajabasa Bandar Lampung, 35141 \\ ${ }^{*}$ E-mail korespondensi: eka.yuda@ fisip.unila.ac.id
}

Diterima: 08 Juni 2020 | Direvisi: 29 Juni 2020 | Disetujui: 29 Juni 2020 | Publikasi online: 10 Juli 2020

\begin{abstract}
This research was conducted to analyze the trend of cyber media reporting in Lampung on the SPAM project from August 2018 to May 2020. The purpose of this study is to explore how cyber media report SPAM project. This study used quantitative content analysis by using categories developed by Irina Wolf. The indicated that that the quality of news on SPAM project in Lampung tends to be negative that hightlight the accident, congestion, damaged roads, and floods caused by the project. The negative tone in the news content is also supported by the use of published article keywords. In terms of publication times, it also proves that the media tend to publish articles only when it is about disaster occurred from SPAM project. This study also showed that there is a relationship between the media and the type of content as well as the atmosphere of the news. In addition, news about the SPAM project in Lampung only published in certain time or several months.
\end{abstract}

Keywords : cyber media, news trend, quantitative content analysis

\section{ABSTRAK}

Penelitian ini dilakukan untuk menganalisis tren pemberitaan media siber di Lampung terhadap proyek SPAM sejak Agustus 2018 hingga Mei 2020. Tujuan dari penelitian ini untuk memperoleh informasi mengenai gambaran pemberitaan secara lengkap terhadap peristiwa dan implementasi pelaksanaannya. Penelitian ini menggunakan analisis isi kuantitatif dengan menggunakan kategori yang dikembangkan oleh Irina Wolf. Hasil penelitian ini menunjukkan bahwa kualitas pemberitaan tentang proyek SPAM di Lampung cenderung negatif yang mengungkapkan musibah kecelakaan, kemacetan, jalan rusak, dan banjir yang disebabkan oleh proyek tersebut. Suasana negatif pada isi pemberitaan didukung juga dengan penggunaan kata kunci artikel yang dipublikasikan. Dari segi waktu penerbitan dapat dibuktikan pula bahwa kedua media cenderung menerbitkan artikel ketika terjadi musibah akibat proyek tersebut. Penelitian ini juga menunjukkan terdapat hubungan antara media dengan jenis konten sekaligus dengan suasana berita. Selain itu, pemberitaan tentang proyek SPAM di Lampung tidak menunjukkan jumlah relatif baik dari segi waktu penerbitannya yang hanya pada bulan tertentu.

Kata kunci : analisis media kuantitatif, media siber, tren berita

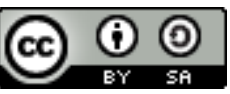

Content from this work may be used under the terms of theCreative Commons Attribution-ShareAlike 4.0

International. Any further distributionof this work must maintain attribution to the author(s) and the title of the work, journal citation and DOI.

Published under Department of Communication and Community Development Science, IPB University and in association with Forum Komunikasi Pembangunan Indonesia and Asosiasi Penerbitan Jurnal Komunikasi Indonesia. 


\section{PENDAHULUAN}

Sistem penyediaan air minum (SPAM) di Lampung merupakan salah satu daftar agenda program strategis nasional (PSN) yang menggunakan anggaran biaya Rp 1,26 triliun untuk membangun pipa transmisi sepanjang $22 \mathrm{~km}$ (detik.com, 2018). Pada proses pemasangan pipa transmisi ini dibutuhkan proses penggalian tanah yang membentang dari kota Bandarlampung hingga kecamatan Natar Lampung Selatan. Lokasi penggalian untuk pemasangan pipa transmisi tersebut sangat bersinggungan dengan arus lalu lintas dan kendaraan yang ramai.

Proyek SPAM telah dimulai pada Agustus 2018 (Lampost.co, 2018) dan diprediksi akan selesai pada tahun 2020. Proyek SPAM diperkirakan dapat melayani 300 ribu jiwa yang ada di 8 kecamatan di Bandarlampung dengan jumlah rumah 60 ribu sambungan (Lampost.co, 2018). Dampak negatif dari proyek ini adalah terjadinya kemacetan panjang serta kecelakaan yang memakan korban jiwa, sehingga banyak media massa yang meliput berita terkait dengan proyek SPAM dari Agustus 2018 hingga Mei 2020. Berita yang diterbitkan oleh media massa memperhatikan beberapa aspek unsurunsur komunikasi, seperti pesan (message), komunikator (receiver), dan dampak (effect) (West \& Turner, 2017).

Media massa memiliki peran sentral dalam penyampaian informasi untuk masyarakat. Media massa dapat mendukung keterbukaan informasi publik dan mampu membingkai isu yang berdampak pada reputasi objek dari pemberitaan tersebut. Istilah objek dari pemberitaan sudah digunakan oleh Budhirianto et al., (2018) sebagai objek pemberitaan. Termasuk proyek pembanguan SPAM di Lampung dapat menjadi objek pemberitaan sebagai jalur komunikasi antara pemerintah dengan masyarakat. Dengan dijadikan objek pemberitaan proyek SPAM di Lampung mendapatkan dua keuntungan yaitu sebagai pembentukan opini masyarakat sekaligus dapat melaksanakan amanat keterbukaan informasi publik.

Amanat keterbukaan informasi publik pada UU Keterbukaan Informasi Publik (KIP) menegaskan pengawasan publik perlu dilaksanakan dalam penyelenggaraan negara dan badan publik karena berdampak pada kepentingan publik (masyarakat). Media massa dapat berperan dalam menjembatani dan mengawasi keterbukaan informasi public. Hal ini seperti yang diungkapkan oleh Nasution (1996), dimana "komunikasi pembangunan meliputi peran dan fungsi komunikasi (sebagai suatu aktivitas pertukaran pesan secara timbal balik) diantara semua pihak yang terlibat, terutama antara masyarakat dengan pemerintah." Vivian (2015) juga mengatakan bahwa, "media adalah pemghubung antara pemerintah dan cara orang memandang pemerintah." Cara orang memandang ini merupakan citra yang dibentuk oleh opini-opini media massa. Sehingga upaya yang dihasilkan oleh kerjasama antara pemerintah dan media massa dapat mempengaruhi cara berpikirnya masyarkat bukan tentang apa yang mereka pikirkan. Ini merupakan langkah yang dapat dilakukan pemerintah sebagai lembaga atau organisasi publik untuk membentuk citra dan reputasi.

Penelitian-penelitian menemukan bahwa citra organisasi yang dibuat oleh media massa merupakan hasil dari intepretasi pemikiran dan penafsiran media itu sendiri. Seperti hasil penelitian yang dilakukan Sulistyasningtyas (2004), "citra dari media massa sebagai citra-citraan yang dimuat oleh media memiliki implikasi penting bagi organisasi", sedangkan pada organisasi pemerintahan selain melalu media massa dipengaruhi oleh birokrasi dan sumber daya organisasi itu sendiri (Indah \& Hariyanti, 2018).

Syarat utama dalam melaksana keterbukaan informasi publik ditentukan oleh tujuan organisasi. Kadoy (2016) mengatakan dalam menjalankan keterbukaan informasi publik tidak boleh memiliki syarat nilai yang perlu diperhatikan adalah kepentingan sasaran kelompok dan peran organisasi pemerintah. Jadi organisasi dapat menentukan masyarakat mau berpikir seperti apa bukan masyarakat yang menentukan opininya tetapi masih banyak masyarakat yang belum memahami tentang pentingnya keterbukaan informasi publik terutama yang berkaitan dengan pembangunan sarana publik karena masih kurangnya sosialisasi terkait program-program pembangunan (Setiaman et al., 2013).

Permasalah lain jika pemerintah tidak melakukan keterbukaan informasi publik maka pemberitaan yang beredar bisa berbagai macam opini tidak ada yang mengontrol pemberitaan yang dilakukan oleh media massa karena pemberitaan yang dibuat akan selalu dipengaruhi oleh faktor-faktor tertentu. Dalam bukunya Vivian (2015) mengatakan terdapat beberapa faktor yang dapat memengaruhi isi dan penerbitan berita, yaitu jurnalis, news hole, aliran berita, perepsi tentang audien, ketersediaan materi, persaingan industri, iklan, kebijakan perusahaan, dan tekanan dari sumber berita. Pemberitaan yang 
dilakukan oleh pemerintah akan selalu bebas karena media massa tidak memiliki banyak informasi sehingga dapat memberikan opini dengan memberikan realitas pemberitaan secara tidak utuh.

Media massa yang menjadi fokus pada penelitian ini adalah Lampung.Tribunnews.com dan Lampost.co. Berdasarkan hasil pengumpulan data yang dilakukan pada bulan Maret 2020, kedua media online ini merupakan media massa yang paling banyak dikunjungi (lihat Tabel 1). Kedua media online tersebut merupakan afiliasi dari surat kabar harian Tribun Lampung yang merupakan bagian grup dari Kompas Gramedia, sedangkan Lampost.co merupakan afiliasi dari surat kabar harian Lampung Post dan bagian dari grup Media Indonesia.

Tabel 1. Data pengunjung dan ranking media online di Lampung pada bulan Maret 2020

\begin{tabular}{llllll}
\hline No. & Nama Media & Total Visits & Global Rank & Country Rank & Category Rank \\
\hline 1 & Lampung.Tribunnews.com & 5.490 .000 & 174 & 5 & 29 \\
2 & Lampost.co & 754.292 & 87.057 & 2.7115 & 7.284 \\
3 & Saibumi.com & 500.970 & 129.020 & 5.286 & 10.155 \\
4 & Teraslampung.com & 484.210 & 132.937 & 8.889 & 10.386 \\
5 & Kupastuntas.com & 382.470 & 158.080 & 8.308 & 11.946 \\
6 & Radarlampung.co.id & 264.261 & 197.181 & 5.234 & 14.249 \\
7 & Rilis.id & 214.741 & 229.907 & 12.538 & 16.164 \\
8 & Duajurai.co & 30.000 & 1.095 .066 & 25.291 & 49.961 \\
\hline Sum & Olah. & & &
\end{tabular}

Sumber: Olah data Similar Web, 20 Mei 2020

Dari studi pustaka yang dilakukan melalui internet ditemukan bahwa kedua media tersebut melakukan liputan berkaitan dengan proyek SPAM sejak tahun 2018. Lampung.Tribunnews.com telah menerbitkan berita proyek SPAM sebanyak 33 artikel sejak 26 Juni 2018 sedangkan Lampost.co menerbitkan sebanyak 44 artikel sejak 25 Juni 2018.

Melalui isi teks pemberitaan dapat dilakukan pemetaan terhadap tren pemberitaan proyek SPAM yang dilakukan oleh kedua media tersebut. Hal ini dilakukan untuk mengetahui bagaimana liputan berita yang telah dilakukan oleh media siber di Lampung dengan menggunakan analisis isi dengan metode kuantitatif. Neal (2012) menyatakan bahwa analisis konten dibagi menjadi dua yaitu metode kuantitatif dan kualitatif dapat digunakan secara terpisah atau bersama-sama. Analisis konten kuantitatif dapat secara singkat didefinisikan sebagai analisis karakterisitik pesan yang sistematis dan objektif (Neuendorf, 2002). Analisis konten dengan pendekatan kuantitatif sudah dilakukan pada akhir 1940-an Lasswell untuk memeriksa perubahan dalam sistem politik internasional dengan melihat 60 tahun editorial di lima surat kabar dunia (Riffe et al., 2005).

Untuk penelitian dengan metode kuantitatif telah dilakukan oleh beberapa peneliti, seperti Wolf (2006) yang menggunakan empat indikator pengukuran terhadap pemberitaan Hizb ut-Tahrir in Kyrgyzstan, Sjøvaag \& Stavelin (2012) pada media web yang digunakan untuk mengukur kedalaman dan skala analisis. Darwadi \& Ashaf (2017) menggunakan metode yang sama untuk mengukur tren cerpen pada surat kabar Kompas.com, dan Wahono et al. (2017) menggunakan metode campuran kuantitatif dan kualitatif pada Radar Madiun dengan objek dua kabupaten yang berbeda. Sedangkan untuk metode kualitatif seperti yang digunakan Elo et al. (2014) metode kualitatif pada penelitian analisis isi untuk mengukur tingkat kepercayaan pada berita dan Lestari (2017) trend pada media sudah pernah dilakukan seperti trend pemberitaan media online dengan metode kualitatif. Berbeda dengan penelitian sebelumnya, tidak ada yang membandingkan peran media massa yang berbeda terhadap isu yang sama maka penelitian ini fokus pada kedua media massa berbeda dengan isu yang sama, yaitu media Lampost.co dan Lampung.Tribunnews.com. Rumusan masalah dari penelitian ini dilakukan untuk mengetahui bagaimana peran media massa pada media siber di Lampung terhadap kualitas informasi dalam pemberitaan proyek SPAM di Lampung?

Tujuan dari penelitian untuk mengetahui hipotesis yang terdiri dari: (H1) jumlah artikel meningkat dari waktu ke waktu; (H2) jumlah artikel musibah tentang proyek SPAM di Lampung akan lebih banyak dibandingkan dari jumlah artikel informatif dan artikel yang tidak berkaitan; (H3) banyaknya 
artikel yang cenderung negatif pada proyek SPAM di Lampung, (H4); ada hubungan antara media yang cenderung dengan suasana negatif akan banyak menghasilkan artikel dengan isu musibah; (H5) ada korelasi antara media dengan jenis konten; dan (H6) ada korelasi antara media dengan suasana berita.

\section{METODE}

Penelitian ini menggunakan metode analisis isi kuantitatif (quantitative content analysis) yang mengacu pada karya Wolf (2006). Wolf melakukan empat kategori analisis pada penelitiannya, yaitu years (tahun/waktu), content (isi), tone (suasana), dan authors (penulis). Penelitian ini akan membuat korelasi antar masing-masing variabel maupun menganalisis variaben dependen dengan data-data yang telah dikumpulkan dengan menggunakan lembar koding (coding sheet).

Kolom lembar koding digunakan untuk mentabulasikan jumlah artikel yang berkaitan dengan proyek SPAM di Lampung yang diterbitkan oleh Lampung.Tribunnews.com dan Lampost.co. Seluruh yang diterbitkan dari kedua media tersebut akan diseleksi berdasarkan periode Januari 2019 hingga Januari 2020. Dari hasil seleksi yang dilakukan berdasarkan periode yang telah ditentukan menghasilkan 46 artikel yang terdiri dari 19 artikel Lampung.Tribunnews.com dan 27 artikel Lampost.co. Tabulasi menggunakan Excel juga digunakan untuk membuat data presentasi grafik.

\section{HASIL DAN PEMBAHASAN}

Indikator pertama yang digunakan adalah tahun. Tahun yang dijelaskan oleh Wolf dalam penelitiannya yaitu berkaitan dengan waktu artikel diterbitkan. Temuan data dari kedua media berdasarkan waktu pernebitan artikel yaitu pada periode Januari 2019 sampai dengan Januari 2020. Temuan ini menunjukkan terdapat $4(15 \%)$ artikel yang diterbitkan Lampost.co pada Januari 2019, 2 (7\%) pada Februari 2019, 2 (7\%) Oktober 2019, 7 (26\%) Desember 2019, dan 9 (33\%) pada Januari 2020. Sedangkan untuk media Lampung.Tribunnews.com, 3 (16\%) artikel pada Januari 2019, 2 (11\%) Mei 2019, 3 (16\%) Juni 2019, 4 (21\%) Oktober 2019, 3 (16\%) Desember 2019, dan 3 (16\%) Januari 2020. Dari kedua media jumlah artikel yang diterbitkan dalam watu 1 tahun untuk setiap bulannya jumlahnya tidak sama.

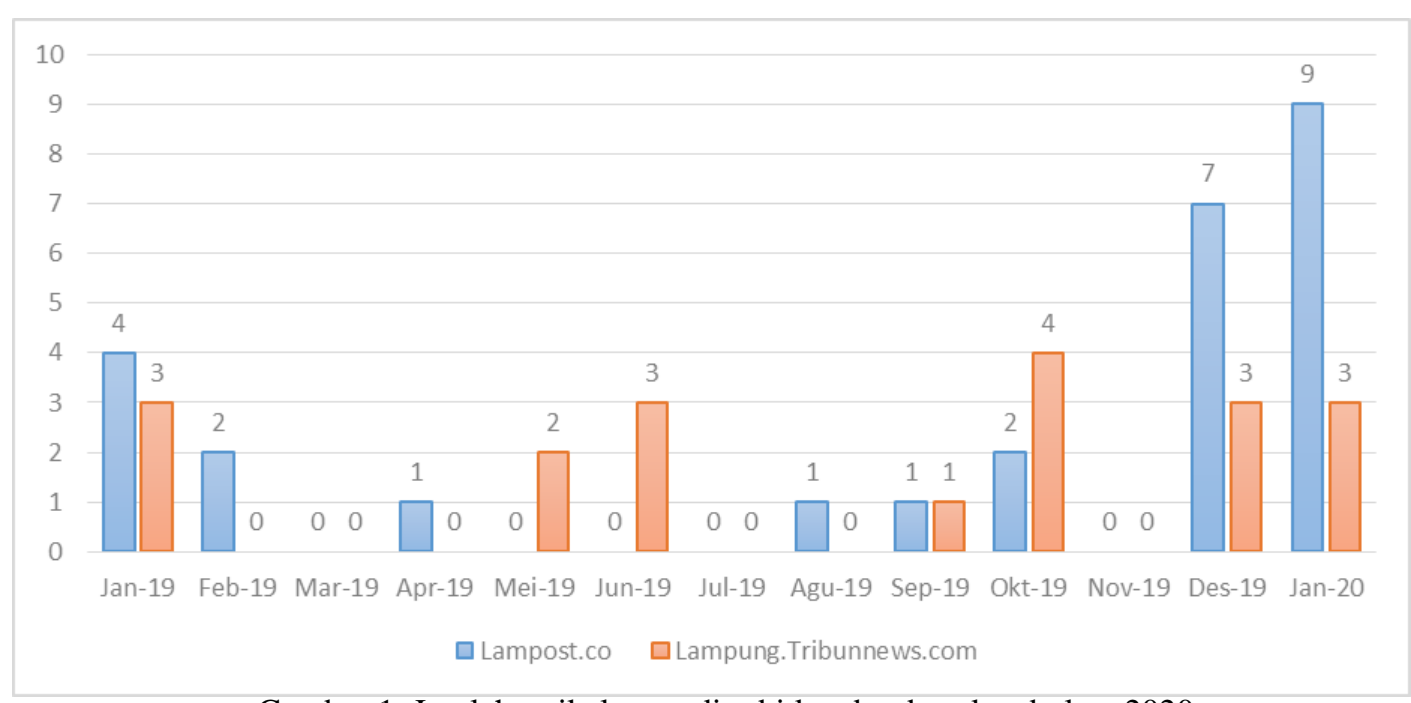

Gambar 1. Jumlah artikel yang diterbitkan berdasarkan bulan, 2020

Artikel yang dipublikasikan berkaitan dengan proyek SPAM di Lampung sudah dimulai sejak tahun 2018 dengan memberitakan perencanaan dan pelaksanaan teknis dari proyek tersebut. Artikel yang diterbitkan oleh kedua media tidak mengalami peningkatan dari waktu ke waktu. Jumlah artikel (lihat Gambar 1) lebih banyak pada Januari 2019 dan Januari 2020. Pada bulan Januari 2019 terdapat 4 artikel dari Lampost.co dan 3 artikel dari Lampung.Tribunnews.com (lihat Gambar 1) yang sama-sama memberitakan tentang terjadinya kasus korupsi dimana tersangkanya adalah pejabat yang terlibat pada 
proyek SPAM di Lampung. Kedua media ini juga melakukan pemberitan terhadap dampak awal dari masalah tersebut, Lampost.co memberitakan tentang lokasi proyek pembangunan SPAM di Rajabasa terlampau sepi, di lokasi tersebut merupakan pengerjaan pembangunan intake dan water treatment plan (WTP) yang harus selesai pada 12 Agustus 2019 dan Lampung.Tribunnews.com memberitakan tentang proyek yang terancam molor dengan kejadian OTT pejabat pada proyek SPAM di Lampung oleh KPK.

Pada Desember 2019 dan Januari 2020 jumlah artikel yang diterbitkan meningkat lagi. Meningkatnya artikel pada dua bulan tersebut disebabkan oleh adanya kejadian kecelakaan yang menewaskan ibu dan bayinya. Kedua media juga menerbitkan artikel tentang truk yang masuk lubang dan mengakibatkan kemacetan parah. Pada dua bulan terakhir, jumlah artikel yang diterbitkan oleh Lampost.co lebih banyak dibandingkan Lampung.Tribunnews.com. Lampost.co juga melihat terdapat permasalahan lain yang disebabkan oleh proyek SPAM, yaitu drainase yang tertutup dan berakibat bajir.

Dari jumlah artikel yang diterbitkan oleh kedua media berdasarkan waktu tidak menunjukkan signifikansi pada setiap bulannya. Bahkan pada bulan-bulan tertentu tidak ditemukan berita tentang proyek SPAM. Hal ini menunjukkan bahwa masing-masing media tidak memberitakan secara lengkap karena berdasarkan waktu jumlah artikel yang diterbitkan tidak mengalami kenaikan (H1).

Media siber memiliki karakteristik berbeda dengan media tradisional. Menurut James C. Foust salah satunya yaitu unlimited space, dimana media online dapat memberitakan secara lengkap ketimbang media lainnya (Romli, 2017). Karakteristik dari media siber membuat kondisi dimana informasi begitu melimpah atau menurut Briggs \& Burke (2000) dikenal dengan istilah cornucopia (banjir informasi) atau dapat memberikan informasi yang lengkap. Hal ini senada yang diungkapkan oleh Gerald L. Baron dalam Anggoro (2011), bahwa media selalu berusaha memberi informasi yang lengkap dan dalam kepada audiensnya. Dari kedua pendapat tersebut menunjukkan bahwa dengan kemampuan media online pemberitaan harus dapat dilakukan secara lengkap. Termasuk pada pemberitaan tentang proyek SPAM di Lampung merupakan isu panjang yang harusnya dapat disaksikan oleh masyarakat pada setiap perkembangan dan kejadiannya. Setelah mengidentifikasi jumlah artikel yang diterbitkan, perlu diketahui kecenderungan isi pada artikel yang diterbitkan. Identifikasi isi artikel menggunakan tiga kategori isi untuk membedakan masing-masing artikel yang telah diterbitkan. Kategori yang digunakan yaitu musibah, informatif, dan tidak berkaitan. Kategori musibah merupakan sekolompok artikel yang pemberitaannya tentang kemalangan yang diakibatkan oleh proyek SPAM, seperti kecelakaan, kemacetan, adanya korban, maupun dampak merugikan lainnya. Untuk kategori informatif merupakan pemberitaan yang selalu berkaitan langsung dengan proyek SPAM di Lampung, seperti aktivitas yang berlangsung, jadwal penyelesaian yang mundur, progres perkembangan proyek, hingga kunjungan pejabat daerah ke proyek tersebut. Kategori yang ketiga yaitu informasi tidak terkait proyek SPAM di Lampung secara langsung seperti kasus korupsi.

Media Lampost.co menerbitkan 14 artikel (52\%) termasuk kategori musibah, 8 artikel (30\%) termasuk kategori informatif, dan 5 artikel (19\%) tidak berkaitan dengan proyek SPAM di Lampung. Media Lampung.Tribunnews.com menerbitkan 6 artikel (32\%) pada kategori musibah, 11 artikel (58\%) informatif, dan 2 artikel (11\%) yang tidak berkaitan. Jumlah ini menunjukkan bahwa H2 diterima, yang diartikan jumlah artikel musibah tentang proyek SPAM di Lampung lebih banyak dibandingkan dengan artikel informatif dan artikel yang tidak berkaitan dari jumlah yang terbitkan kedua media.

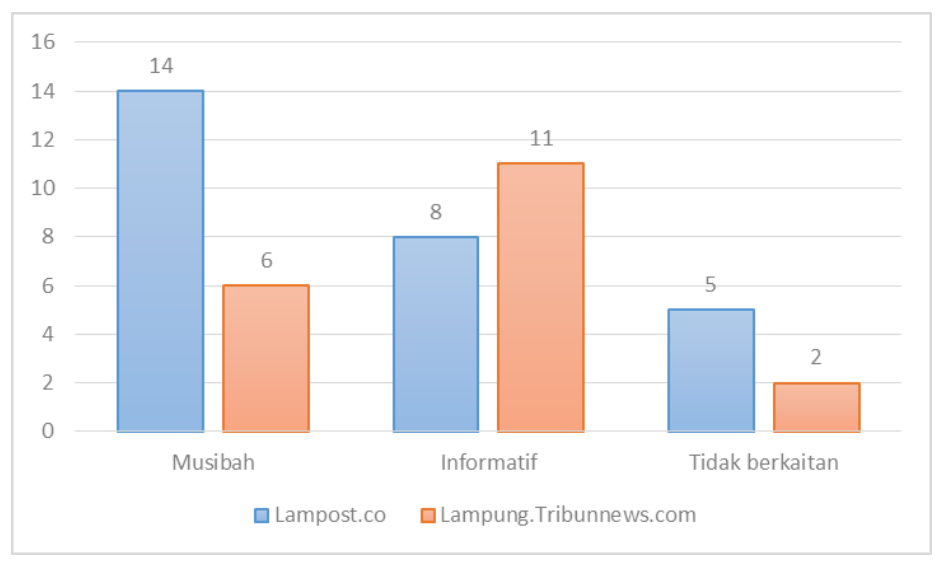

Gambar 2. Isu pemberitan melalui isi berita, 2020 
Dalam unsur syarat terjadinya komunikasi, isi merupakan bagian penting dalam proses transaksional informasi antara komunikator (pekerja media) dan komunikan (pembaca). Isi pada berita memang akan mempengaruhi dampak pada persepsi atas gagasan yang diberitakan oleh media. Jika kita melihat pada teori media pebangunan ole McQuail atas asumsi dasarnya terhadap teori tersebut bahwa media hendaknya menerima dan melaksanakan tugas pembangunan positif sejalan dengan kebijaksanaan yang ditetapkan (Musa, 1997). Seluruh artikel yang diterbitkan oleh kedua media menunjukkan kejadian yang berdampak negatif lebih sering terjadi pada pelaksaan proyek tersebut tetapi hal ini dapat diantisipasi dengan melakukan manajemen isu oleh pelaksana proyek atau pemerintah sehingga isu musibah dapat dikendalikan dengan isu-isu yang berkaitan pada pembangunan proyek.

Dengan banyaknya isu musibah yang dipublikasikan (lihat Gambar 4) dapat dilihat pengaruh media pada isu yang dipilih agar dapat menentukan H5 dengan adanya korelasi antara media dengan isi berita. Lampost.co lebih memilih dengan menggunakan isu yang berkaitan dengan musibah yang diakibatkan dari proyek, sedangkan Lampung.Tribunnews.com lebih didominasi oleh berita yang berkaitan dengan informatif, seperti perkembangan proyek SPAM di Lampung yang sudah mencapai target.

Suasana pada artikel mengandung reputasi yang dapat berdampak pada dukungan atau penolakan dari pemberitaan. Dari seluruh berita yang dihasilkan dari kedua media akan menunjukkan kecenderungan pada reputasi tertentu. Media Lampost.co menunjukkan 4 (15\%) artikel yang berkaitan suasana positif, 8 (30\%) netral, dan 15 (56\%) negative. Sedangkan untuk media Lampung.Tribunnews.com menunjukkan kecenderungan 4 (21\%) suasana positif, 4 (21\%) netral, dan $11(58 \%)$ berkaitan suasana negatif. Kedua media tersebut sama-sama menunjukkan kecenderungan suasana negatif pada berita proyek SPAM di Lampung.

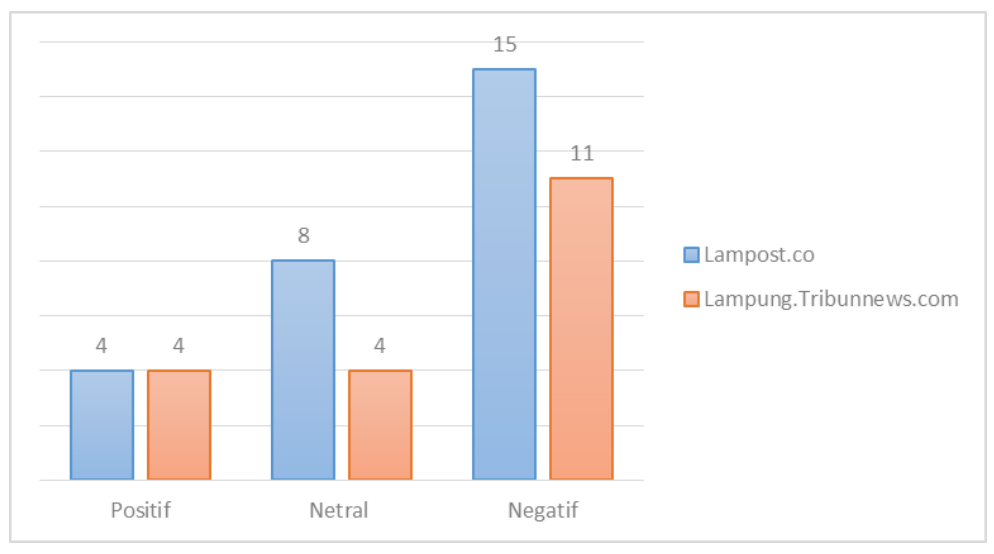

Gambar 3. Tiga kategori suasan pemberitaan dari kedua media, 2020

Untuk menjawab H3 dan $\mathrm{H} 4$, yaitu sebagai dukungan kedua media memberikan gambaran yang seimbang dari proyek SPAM di Lampung. Lalu menunjukkan suasana artikel yang cenderung negatif dengan artikel yang berisi musibah. Artikel yang dihasilkan oleh kedua media memang cenderung negatif yang berisi tentang kejadian pidana, korupsi, kecelakaan, kemacetan, kematian, banjir dan jalan rusak. Makna negatif yang lebih banyak muncul pada setiap artikel berita memang menunjukkan kejadian-kejadian kemalangan.

Suasana berkaitan dengan reputasi dari makna yang dihasilkan oleh berita yang terbagi menjadi 3 yaitu positif, netral, dan negatif. Dari data yang ditemukan seluruh artikel yang dihasilkan oleh kedua media menunjukkan jumlah artikel positif yang diterbitkan Lampost.co dan Lampung.Tribunnews.com sama-sama sebanyak 4 artikel, untuk artikel dengan suasana netral Lampost.co menerbitkan sebanyak 8 artikel. Jumlah ini lebih banyak dari yang diterbitkan oleh Lampung.Tribunnews.com sebanyak 4 artikel. Suasana negatif cenderung lebih banyak dibandingkan jumlah artikel yang dihasilkan oleh kedua media dengan total 26 artikel terdiri dari 15 artikel dari Lampost.co dan 11 artikel dari Lampost.Tribunnews.com. Jika dibandingkan antara jumlah artikel negatif dengan musibah lebih banyak dibandingkan berisi tentang informatif dan tidak terkait dengan proyek SPAM di Lampung. Media Lampost.co jumlah artikel negatif sebanyak 15 dari 11 artikel berisi tentang musibah sedangkan Lampung.Tribunnews.com dari 11 artikel negatif , dimana 6 diantarnya berisi tentang musibah. Hasil ini menunjukkan bahwa $\mathrm{H} 4$ yaitu ada hubungan antara kecenderungan artikel dengan suasana negatif dengan artikel berisi tentang musibah. 
Tiga kategori suasana yang digunakan dilakukan untuk membandingkan antara kedua media yang mempengaruhi suasana artikel berita H6. Dari data yang ditemukan kedua media cenderung menerbitkan artikel dengan suasana negatif yang berisi tentang musibah. Artinya, suasana berita yang negatif sangat dipengaruhi oleh isu berita yang telah dipilih oleh media untuk diterbitkan.

Faktor lain yang mempengaruhi isi dan suasana yaitu penulis. Menurut Shoemaker \& Reese (1996) salah satu faktor yang mempengaruhi isi media adalah faktor individu, salah satunya penulis atau reporter dari media. Kedua media memiliki tim kecil yang berisi tentang 6 sampai 8 orang untuk melakukan liputan terhadap proyek tersebut. Pada setiap penulis akan menghasilkan kecenderungan tertentu, baik dari isi dan suasana pada setiap tulisannya.

Hal lain juga ditemukan bahwa artikel yang diterbitkan juga berasal dari republish yang berasal dari media afiliasi kedua media. Berasal dari Lampost.co terdapat 6 penulis dan 3 re-publish, 7 (26\%) berasal dari Setiaji B. Pamungkas, 5 (19\%) dari Muharram C. Lugina, $4(15 \%)$ dari Winarko, $1(4 \%)$ Adi Sunaryo, 5 (19\%) dari Deta Citrawan, 1 (4\%) dari Asrul S. Malik,1 (4\%) dari Media Indonesia, 2 (7\%) dari Antara, dan 1 (4\%) dari Medcom.id. Tidak berbeda dengan Lampost.co, Lampung.Tribunnews.com juga menggunakan beberapa artikel yang dihasilkan perusahan afiliasi tetapi Lampung.Tribunnews.com memiliki jumlah penulis yang lebih banyak walaupun jumlah artikel yang diterbitkan lebih sedikit terdiri dari 8 penulis dan 2 re-publish, $3(16 \%)$ berasal dari Bayu Saputra, $1(5 \%)$ V. Soma Ferrera, 4 (21\%) dari Hanif Mustafa, 3 (16\%) Sulis S. Markhamah, $2(11 \%)$ Eka A. Sholichin, 1 (5\%) Dewi Anita, 1 (5\%) Romi Rinando, 1 (5\%) Muhammad H. Kusuma, 2 (11\%) dari Tribunnews.com, dan 1 (5\%) dari RRI.

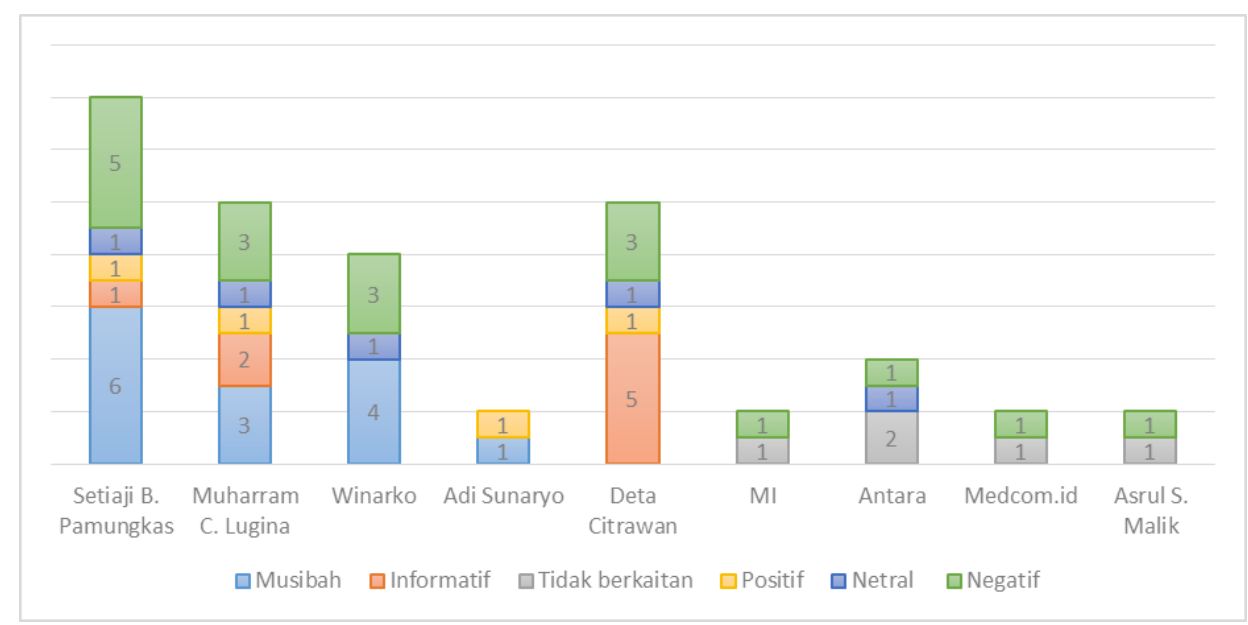

Gambar 4. Artikel yang diterbitkan Lampost.co berdasarkan penulis berkaitan dengan isi dan suasana berita, 2020

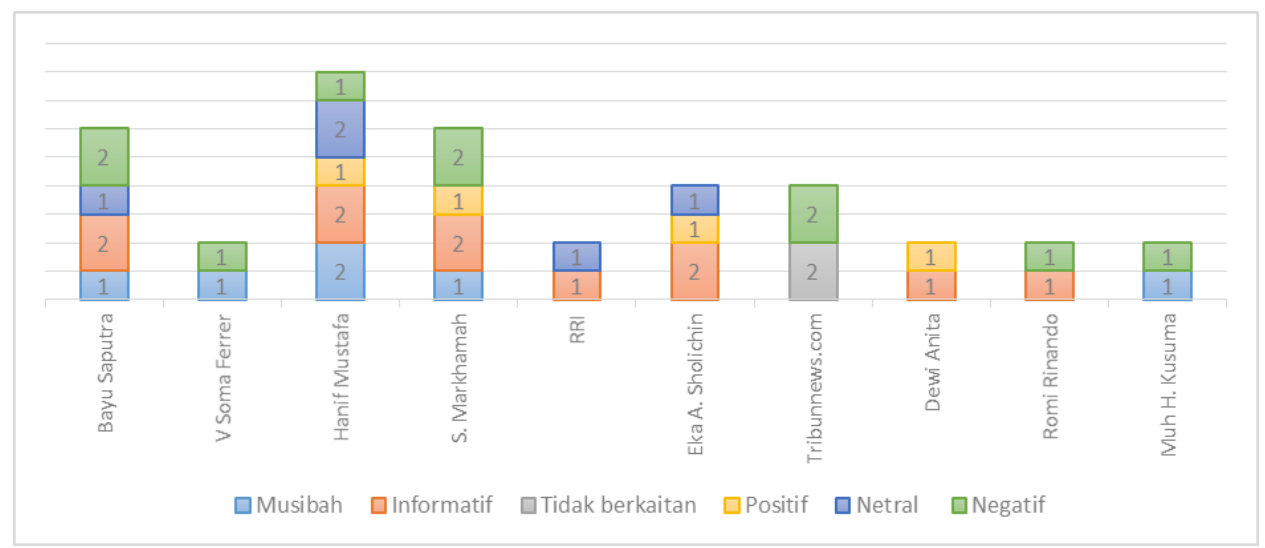

Gambar 5. Artikel yang diterbitkan Lampung.tribunnews.com berdasarkan penulis berkaitan dengan isi dan suasana berita, 2020 
Seluruh artikel yang dihasilkan oleh penulis mengandung unsur isi (content) dan suasana (tone) terhadap pemberitaannya (lihat gambar 4 dan gambar 5). Shoemaker \& Reese (1996) menjelaskan bahwa isi berita dapat dipengaruhi dari latar belakang komunikator, seperti: pendidikan, sikap politik, kepercayaan agama, hingga lingkungan kerja mereka. Vivian (2015) juga menjelaskan bahwa jurnalis membuat keputusan penting tentang apa peristiwa, fenomena, dan isu yang akan dilaporkan dapat menentukan berita mana yang akan dilaporkan, dikabarkan, dan juga bagaimana cara pemberitaannya. Faktor di atas menjelaskan bahwa pemberitaan selalu dipengaruhi oleh penulis yang memiliki pendapatnya sendiri dalam memberitakan peristiwa terkait proyek SPAM di Lampung. Walaupun jumlah artikel yang diterbitkan oleh kedua media tidak menunjukan konsisten pada setiap bulannya, Lampost.co lebih banyak menerbitkan artikel yang berkait dengan isu musibah dan mengandung makna negatif dibandingkan Lampung.Tribunnews.com.

Kata kunci pada penelitian ini berkaitan dengan kata-kata yang sering digunakan pada setiap penulisan berita proyek SPAM Lampung. Seluruh kata kunci yang digunakan merupakan hasil dari penelusuran dari isi (content) dan suasana (tone). Kedua media memiliki kecenderungan yang berbeda-beda pada penggunaan kata kunci, Lampost.co lebih merata dibandingkan media Lampung.Tribunnews.com yang lebih fokus pada kata kunci tertentu. Pada kata kunci yang digunakan sudah dibagi menjadi 20 kategori dengan jumlah kata yang dihasilkan sebanyak 632 kata yang dihasilkan pada kedua media yang terdiri dari 119 (19\%) kata kecelakaan, 49 (8\%) kemacetan, $30(5 \%)$ meninggal, (22 (3\%) kejadian, $4(1 \%)$ kondisi, $2(0,3 \%)$ bahaya, $10(2 \%)$ korban, $21(3 \%)$ memperbaiki, $5(0,8 \%)$ kerusakan, $4(0,6 \%)$ kendala, $119(19 \%)$ galian, 55 (9\%) memprihatinkan, $52(8 \%)$ dampak, $20(3 \%)$ selesai, $45(7 \%)$ pemerintah, $30(4,7 \%)$ kontraktor, $4(0,6 \%)$ peristiwa, $20(3,2 \%)$ informasi, $12(1,9 \%)$ menolak, dan $9(1,4 \%)$ untuk keluhan.

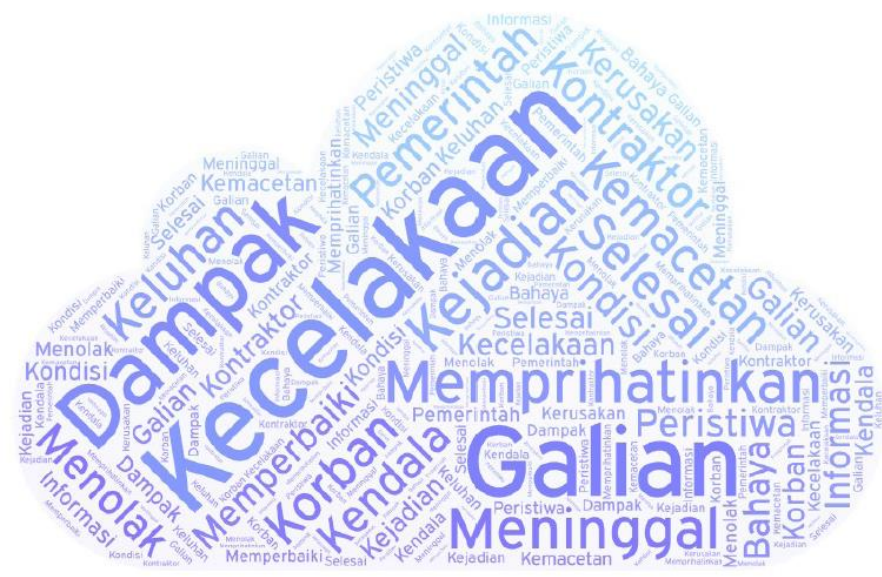

Gambar 6. Kencederungan kata-kata dari kedua media yang digambarkan berbentuk wordcloud, 2020 


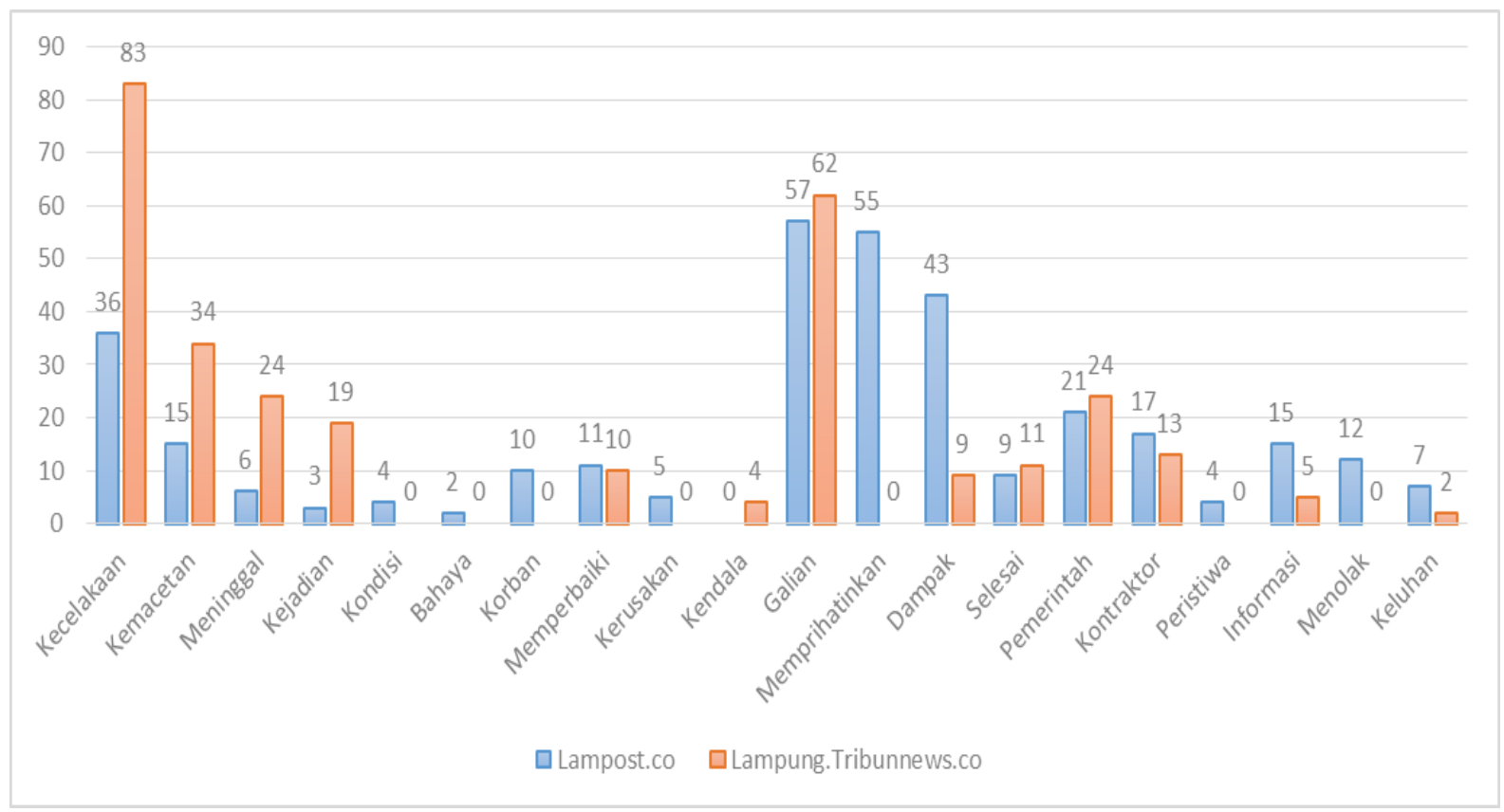

Gambar 7. Kencederungan penggunaan kata dari masing-masing media, 2020

Selain menghasilkan jumlah artikel yang diterbitkan lebih banyak Lampost.co lebih banyak dibandingkan Lampung.Tribunnews.com juga menghasilkan jumlah kata kunci (Gambar 7) lebih banyak. Kata kunci yang dihasilkan oleh Lampost.co sebanyak 332 kata dari 27 artikel sedangkan Lampung.Tribunnews.com sebanyak 300 kata dari 19 artikel. Kecenderungan kata kunci yang digunakan oleh Lampost.co lebih merata dibandingkan Lampung.Tribunnews.com hal ini disebabkan Lampung.Tribunnews.com menghasilkan artikel yang lebih panjang dibandingkan dengan Lampost.co.

Kata kunci yang sering digunakan pada setiap artikel dari kedua media memang menunjukkan kecenderung makna yang negatif, hal ini dapat dibuktikan dengan kata kunci yang sering digunakan seperti kecelakan 83 kata yang digunakan oleh Lampung.Tribunnews.com sedangkan Lampost.co hanya 36 kata, kemacetan Lampung.Tribunnews.com 34 kata Lampost.co 15 kata, meninggal Lampung.Tribunnews.com 24 Lampost.co 6 kata, bahaya Lampung.Tribunnews.co 0 (nol) Lampost.co 2, dan memprihatinkan Lampung.Tribunnews.com 0 (nol) kata Lampost.co 55 kata jadi jumlah kata yang bermakna negatif dihasilkan dari kedua media sebanyak 200 kata (lihat Gambar 7).

\section{KESIMPULAN}

Temuan data dari penelitian ini mengungkapkan bahwa hipotesis utama didukung atau diterima oleh 5 dari 6 hipotesis: (H2) jumlah artikel musibah tentang proyek SPAM di Lampung akan lebih banyak dibandingkan dari jumlah artikel informative dan artikel yang tidak berkaitan, (H3) Banyaknya artikel yang cenderung negatif pada proyek SPAM di Lampung, (H4) ada hubungan antara media yang cenderung dengan suasana negatif akan banyak menghasilkan artikel dengan isu musibah, dan (H5) ada korelasi antara media dengan jenis konten, dan (H6) ada korelasi antara media dengan suasana berita.

Hipotesis (H1) ditolak karena menunjukkan bahwa jumlah artikel yang diterbitkan oleh kedua media sama-sama lebih banyak pada bulan Januari 2019, Desember 2019, dan Januari 2020 yang tidak menunjukkan sebaran secara meningkat. Di bulan yang lain, terbitan tentang proyek SPAM di Lampung hanya berisi tentang kejadian-kejadian tertentu baik suasana positif maupun negatif.

Hasil penelitian ini menunjukkan bahwa kualitas pemberitaan tentang proyek SPAM di Lampung cenderung negatif yang berisi tentang musibah kecelakaan, kemacetan, jalan rusak, dan banjir yang disebabkan oleh proyek tersebut, tetapi isi pemberitaan musibah tidak semuanya dihasilkan oleh tim penulis baik Lampost.co dan Lampung.Tribunnews.com. Hanya terdapat empat orang saja yang pernah menulisnya. Suasana negatif pada isi pemberitaan didukung juga dengan penggunaan kata 
kunci artikel yang dipublikasikan. Dari segi waktu penerbitan juga membuktikan bahwa kedua media cenderung menerbitkan artikel jika terdapat pemberitaan yang selalu berkaitan dengan musibah.

Saran yang dapat diberikan kepada kedua media adalah memperhatikan pemilihan berita yang diterbitkan. Kedua media juga perlu memaksimalkan pemberitaan terhadap pembangunan daerah seperti proyek SPAM di Lampung. Jika terjadi musibah yang disebabkan dari dampak pembangunan kedua media perlu mengklarifikasi atau merujuk sumber berita dari pelaksana proyek agar berita yang diberikan lebih berimbang. Media massa juga perlu dapat memberikan informasi tentang profil penyelenggara proyek jika terjadi permasalahan dalam prosesnya masyarakat dapat memerikan respond secara langsung bahkan dapat menuntun informasi yang akurat. Proses pembanguan daerah tidak dapat dikerjakan sendiri oleh pemerintahnya dan membutuhkan peran media sebagai jembatan antara pemerintah dengan masyarakat sehingga dapat memberikan dampak persepsi yang baik jika terjadi permasalahan dalam proses pembangunan. Pengaruh lain dari dukungan media massa adalah upaya pengawasan publik yang akan sangat berpengaruh pada citra pemerintah. Untuk pemerintahan daerah ataupun pusat perlu memahami komunikasi pembangunan secara utuh sebagai langkah untuk mengontrol informasi sehingga pemberitaan tidak beredar secara bebas dan terciptanya opini publik yang tidak diharapkan pada tujuan pembangunan.

\section{UCAPAN TERIMA KASIH}

Ucapan terima kasih ini saya sampaikan kepada Universitas Lampung atas hibah BLU penelitian yang diberikan. Serta seluruh rekan-rekan dosen yang telah membantu dalam proses penelitian ini, khususnya tim penelitian Trend media siber di Lampung yang telah mendukung data dan analisis penelitian.

\section{DAFTAR PUSTAKA}

Anggoro, A. S. (2011). Detikcom Legenda Media Online. PT Buku Kita.

Briggs, A., \& Burke, P. (2000). A Social History of The Media. Polity Press.

Budhirianto, S., Sumiaty, N., \& Syaidah, S. (2018). Analisis Wacana Media terhadap Kebijakan dan Citra Pemerintah di Surat Kabar Daerah pada Tahun 2017. Jurnal Pikom, 19(2), 101-114.

Darwadi, D., \& Ashaf, A. F. (2017). Trend Tematik Cerpen di Surat Kabar (Cerpen Harian Kompas Periode 1998-2007). Metakom, 1(1), 53-63. https://doi.org/https://doi.org/10.23960/metakom.v1i1.5

Elo, S., Kääriäinen, M., Kanste, O., Pölkki, T., Utriainen, K., \& Kyngäs, H. (2014). Qualitative Content Analysis. SAGE Open, 4(1), 215824401452263. https://doi.org/10.1177/2158244014522633

Indah, T., \& Hariyanti, P. (2018). Implementasi Kebijakan Keterbukaan Informasi Publik pada Dinas Kominfo Kota Tasikmalaya. Jurnal Komunikasi, 12(2), 127-140. https://doi.org/10.20885/komunikasi.vol12.iss2.art3

Kadoy, A. A. (2016). Implementasi Keterbukaan Informasi Publik di Kabupaten Sleman. E Journal Katalogis, 6(2), 154-161.

Lestari, R. D. (2017). QUALITY NEWS DAN POPULAR NEWS SEBAGAI TREND PEMBERITAAN MEDIA ONLINE (Studi Deskriptif Kualitatif Trend Pemberitaan Quality News dan Popular News pada Media Online Nasional di Indonesia Periode 2016). Channel, 5(1).

Luqmanulhakim, F. (2018). Proyek SPAM Ditarget Rampung 2020. Lampost.Co2.

Musa, B. (1997). Uses and abuses ofdevelopment mediatheory in sub-SaharanAfrica: critique of a quasi-descriptive/prescriptivetheory. Ecquid Novi: AfricanJournalism Studies, 18(1), 132-147.

Nasution, Z. (1996). Komunikasi Pembangunan: Pengenalan Teori dan Penerapannya. Raja Grafika Persada.

Neal, M. R. (2012). Media Content Analysis: Qualitative Methods. In The Oxford Handbook of Media Psychology (Issue March 2019, pp. 1-37). Oxford University Press. https://doi.org/10.1093/oxfordhb/9780195398809.013.0029

Neuendorf, K. A. (2002). The Content Analysis Guidebook. Sage Publications, Inc.

Rachman, F. F. (2018). SPAM Lampung Rp 1,26 T Mulai Dibangun. Detik.Com.

Riffe, D., Lacy, S., \& Fico, F. G. (2005). Analyzing Media Messages : Using Quantitative Content 
Analysis in Research. Lawrence Erlabum Associates.

Romli, A. S. M. (2017). Jurnalistik Online. Nuansa.

Sandy, A. Y. (2016). KEBIJAKAN KOMUNIKASI PADA PROYEK EKSPLORASI PANAS BUMI DI BATURADEN DALAM PERSPEKTIF FPIC. Jurnal Penelitin Pers Dan Komunikasi Pembangunan, 19(1), 1-10.

Setiaman, A., Sugiana, D., \& Mahameruaji, J. N. (2013). Implementasi Kebijakan Keterbukaan Informasi Publik. Jurnal Kajian Komunikasi, 1(2), 196-205. https://doi.org/10.24198/jkk.vol1n2.9

Shoemaker, P. J., \& Reese, S. D. (1996). Mediating The Message: Theories of Influences on Mass Media Content. Longman.

Sjøvaag, H., \& Stavelin, E. (2012). Web media and the quantitative content analysis: Methodological challenges in measuring online news content. Convergence, 18(2), 215-229. https://doi.org/10.1177/1354856511429641

Sulistyasningtyas, I. D. (2004). Pemberitaan di Media Massa sebagai Pembentuk Reputasi Organisasi. Jurnal ILMU KOMUNIKASI, I(1), 113-126. https://doi.org/10.24002/jik.v2i2.245

Vivian, J. (2015). Teori Komunikasi Masa. Kencana.

Wahono, H., Hastjarjo, S., \& Adib, A. (2017). Berita Tentang Pemerintah Daerah (Analisis Isi Berita Tentang Pemerintah Kabupaten Ngawi, Madiun dan Magetan). Jurnal Ilmu Komunikasi, 15(1), $39-47$.

West, R., \& Turner, L. H. (2017). Pengantar Teori Komunikasi: Analisis dan Aplikasi (5th ed.). Salemba Humanika.

Wolf, I. (2006). Hizb ut-Tahrir in Kyrgyzstan: Quantitative Media Content Analysis. Journal of Conflict and Communication, 5(2), 1-17.

Zulniadi, D. (2018). Proyek SPAM Bandar Lampung Dimulai Awal Agustus. Lampost.Co. 